\title{
The Dependence of Saudi Universities' Students on Media Regarding Issues of International Terrorism
}

\author{
Dr. Adel Abdulkader Al-Makinzy \\ Department of Mass Communication \\ King Saud University \\ Saudi Arabia
}

\begin{abstract}
The aim of this study is to identify the extent to which Saudi universities' students rely on the media for international terrorism issues, The study used the descriptive analytical method. A questionnaire was developed as a tool to cover the practical side of this study and was constructed for this purpose in accordance with the recognized scientific steps. The tool was applied to the study sample which numbered (200) students from AlImam Mohammad Ibn Saud Islamic University, King Saud University, Dar Al Uloom University and Prince Sultan University. To answer the study questions, descriptive and analytical statistical methods were used through the statistical package (SPSS); frequencies and percentages were extracted, and the Kronbach alpha test was used to identify the stability of the study tool. To answer the study questions arithmetic mean and standard deviations were calculated, and a one Way ANOVA, the Scheffe Test, and the Independent Sample T-test were used. The results found that Saudi universities students relied on the media regarding international terrorism issues. This can be attributed to the true Islamic intellectual vision from which all Saudi university students aspire to renounce violence, extremism and terrorism, as well as their rejection of all forms of destruction that bring ruin and havoc to societies.
\end{abstract}

Keywords: Media - Terrorism - daaesh - University Youth - Newspapers - TV Channels - Social Networks.

\section{Introduction}

Media is one of the most powerful tools of modern communication that enables audience to live in the present and interact with others. It also has an important role in introducing issues related to national security to public opinion. This century is the era of international media and propaganda with all its political, military, economic and social components under the revolution of communication and information (Cole Bunzel, 2015). a revolution that will not stop because of the continuation of innovation and change processes, which led to a huge development in communication and information technology. All this technology development besides the spread of satellites enabled the media messages to spread all around the world making it like one small reachable place(Fawaz A. Gerges,2014). The media and international propaganda in modern times have become part of people's lives. Since the events of September 11, 2001, the Arab and international media have focused on the phenomenon of terrorism and extremism and their repercussions on the Arab region and the world (Adam Bazcko,2016). Any person who is acquainted with the phenomenon of terrorism and extremism finds that this phenomenon is of great interest to people and governments around the world because of its serious impact on the security and stability of States (Government of the United Kingdom,2016). It has become clear that we are facing an organized criminal phenomenon aimed at creating a general atmosphere of fear, terror and threat of violence against individuals and property. This means that this dangerous phenomenon is aimed at destabilizing societies, influencing their political situation and destroying their national economies by killing innocent people to create a state of general chaos. There is reasonable ground for the researcher to carry out this study on international terrorism, because it helps diagnosing the general conditions and atmosphere that are responsible for the spread of terrorism and extremism in the hope of besieging and eradicating it. This study also clarifies the ability of terrorist organizations to recruit media and benefit from the communications revolution in achieving their criminal agenda and plans; as well as revealing these organizations' active presence on the Internet and other media means to sell their destructive ideas and recruit young people (Aldo Borgu, 2016). 
The media has become a dangerous weapon in the hands of terrorists, who can easily send messages that have a negative impact on individuals and communities, broadcast photos and videos that demonstrate their criminality, their extreme darkness believes, and their expiatory of many groups of Arab and non-Arab societies. The media in general attend to events of terrorism and classify them as events of increasing news value, because they have amounting degree of conflict. These events then preside news stories on television, international satellite channels, and the front pages of newspapers. In his study the researcher used the theory of reliance on the media because it is one of the best theories that enable the researcher to study the Saudi university students' reliance on media regarding issues of international terrorism(Christopher M,2017). The researcher also used the study of "Yoo" (2016) entitled "Terrorism, Laws of War and the Constitution". The study addressed three combat cases that represent US primary efforts to establish legal rules in consistence with US constitutional principles, to launch the global war on terror. The critical questions that raised these cases about the balance between national security and civil liberties in wartime were analyzed in addition to a call for a review of the complex relationship between the Constitution and international law. The Abadi and Gardaazial Study, (2015), entitled Terrorism and the Global Economy. The two researchers discussed the impact of terrorism on the global economy, stating in the beginning that they do not support what was said that terrorism has little impact on economic activity concerning that terrorist attacks only destroy a small part of the capital. The researchers argued that the changes in the intensity of terrorism might cause large movements of capital across countries if world economy is open enough.

\section{The study Problem}

The problem of the study is to determine the extent of the danger posed by the phenomenon of international terrorism and its implications for national security, which can lead to the emergence of new security challenges in various areas of life, that is becoming more dangerous with the development of terrorist planning tools and advanced means of implementation based on modern technology. This study aims to identify the extent to which Saudi universities' students rely on the media for international terrorism issues.

\section{Study Questions}

1. The extent to which Saudi universities' students rely on the media regarding international terrorism issues?

2- What are the effects of the Saudi universities students reliance on the media regarding international terrorism issues?

\section{Objectives of the study}

This study aims to achieve the following objectives:

1- Identifying the degree of Saudi universities' students reliance on the media regarding international terrorism.

2 - Identifying aspects of international terrorism that may threaten national and international security.

3 - Determining the impact of terrorism on national and international security.

\section{The importance of the study}

The importance of the study emerges from the fact that it seeks to demonstrate the seriousness of terrorism as an international criminal phenomenon that threatens the security of states, and identifying effective methods to confront them, and mitigate their effects; As well as stressing the importance of developing a strong strategy to

\section{Limitations of the study}

Spatial Limitation: This study was applied to Saudi universities students.

Time Limitation: The study tool was applied during the period from 1/5/2016 to 30/5/2016.

Human Limitation: The study tool was applied equally to the students of Al-Imam Mohammad Ibn Saud Islamic University, King Saud University, Dar Al Uloom University, and Prince Sultan University.

Methodology: This study used a descriptive analytical method to identify the Saudi universities' students reliance on the media regarding international terrorism.

The study sample: The study sample consisted of (200) students from Al-Imam Mohammad Ibn Saud Islamic University, King Saud University, Dar Al Uloom University and Prince Sultan University distributed equally.

Study tool: A questionnaire was used as a tool to cover the applied side of this study. It was developed for the study according to the recognized scientific steps applied to the study sample. 


\section{Validity and Reliability}

The questionnaire was presented to a number of arbitrators and specialists, to verify the validity and consistency of their paragraphs until the study tool emerged in its final form. The study considered the opinions of the arbitrators and their alterations as a sign of validity and reliability of the study tool content and the adequacy of its variability and diversity. After making the required adjustments, a balance was achieved between the contents of the study tool in its paragraphs, which confirms the validity and reliability of the tool.

\section{Results and discussion}

To answer the first question of the first study, arithmetical averages and standard deviations of the responses of the sample members were calculated, and Table (1) illustrates the results.

Table 1: Arithmetical averages, standard deviations and levels of respondents 'responses to the paragraphs of Saudi universities students' reliance on the media regarding issues of international terrorism

\begin{tabular}{|l|l|l|l|l|l|}
\hline$\#$ & Paragraph & $\begin{array}{l}\text { Arithmetic } \\
\text { mean. }\end{array}$ & $\begin{array}{l}\text { Standard } \\
\text { deviation }\end{array}$ & rank & level \\
\hline 12 & $\begin{array}{l}\text { The Arab satellite channels offer programs to identify the } \\
\text { details of the issue of terrorism and extremism and its } \\
\text { sources }\end{array}$ & 4.15 & 1.45 & 1 & high \\
\hline 6 & $\begin{array}{l}\text { The media use strategic experts to employ the media style } \\
\text { that contributes to reducing the phenomenon of terrorism } \\
\text { and extremism }\end{array}$ & 4.12 & 1.28 & 2 & high \\
\hline 7 & $\begin{array}{l}\text { The media have contributed to reducing the phenomenon } \\
\text { of terrorism and extremism }\end{array}$ & 4.6 & 1.29 & 3 & high \\
\hline 4 & $\begin{array}{l}\text { The media focus on the stereotype of military warfare, } \\
\text { leading to the phenomenon of terrorism and extremism }\end{array}$ & 4.3 & 1.33 & 4 & high \\
\hline 5 & $\begin{array}{l}\text { The media are supportive of some military factions by } \\
\text { promoting them }\end{array}$ & 3.98 & 1.28 & 5 & high \\
\hline 1 & $\begin{array}{l}\text { Influence on public opinion is the priority of extremist } \\
\text { terrorist organizations through the media }\end{array}$ & 3.97 & 1.45 & 6 & high \\
\hline 3 & $\begin{array}{l}\text { The media are supportive of the principle of political } \\
\text { propaganda that is based on combating terrorism and } \\
\text { extremism }\end{array}$ & 3.94 & 1.24 & 7 & high \\
\hline 8 & $\begin{array}{l}\text { Satellite channels such as Arabia, BBC and others have } \\
\text { had a negative impact on the transfer of events }\end{array}$ & 3.88 & 1.27 & 8 & high \\
\hline 9 & $\begin{array}{l}\text { media is capable of contributing to the awareness of the } \\
\text { dangers of terrorism and the means to fight it }\end{array}$ & 3.73 & 1.46 & 9 & high \\
\hline 10 & $\begin{array}{l}\text { The media have a role in building values of tolerance, } \\
\text { justice and coexistence }\end{array}$ & 3.65 & 1.25 & 10 & high \\
\hline 11 & $\begin{array}{l}\text { The media address the motives of terrorism and identify } \\
\text { its causes }\end{array}$ & 3.58 & 1.40 & 11 & high \\
\hline 2 & $\begin{array}{l}\text { Extremist terrorist organizations make use of social } \\
\text { networks to spread terror and fear among the audience }\end{array}$ & 3.52 & 1.42 & 12 & high \\
\hline Weighted average & 3.88 & 1.49 & - & high \\
\hline
\end{tabular}

Table (1) shows that the arithmetic average of students' responses to their reliance on the media regarding terrorism issues was 3.88, which is high level. The arithmetic averages of the media role ranged between lowest and highest average (3.52 - 4.15) The rise in arithmetic average of students 'responses to the paragraphs of their reliance on media regarding terrorism issues can be explained by the students' beliefs in the importance of the media and its ability to combat terrorism and extremism by using all available means to prepare and broadcast press reports on this dangerous phenomenon to reveal the falsehood that surrounds it. In addition to the students' awareness of their rejection of violence and aggression that caused the peoples of the Arab region tragedies and destruction. Table (1) also shows the arithmetic averages and standard deviations of students' responses to each paragraph of Saudi students' reliance on media regarding issues of terrorism, in a descending order, we will find that the highest arithmetic average of this value was paragraph (12) the explanation for this is because Arabic satellite channels introduce programs and studies done by strategic experts on terrorism issues, The media also 
focus on the stereotype of military warfare between states and extremist terrorist organizations, Which gives the audience a clear picture of the shape and path of these brutal and destructive organizations. The lowest arithmetic mean was for paragraph (2). This was due to the media strategy, and public relations' ability to attract young men and women to join the alleged extremist terrorist organizations, in addition to the power of the messages they promote through social networks. It was noted that the researchers of terrorism, including GM Berger, tracked about 3 million Twitter for these organizations on Twitter, he found that it was driven by more than 7,500 accounts run by extremist terrorist organizations, in addition to the accounts of their supporters on Facebook, Twitter, Instagram and YouTube, using jihadi hash tags. However, a large number of these accounts were shut down after these extremist organizations were placed on the terrorism list and the operations against them began. The table also shows that all the related paragraphs in the Saudi universities students' reliance on the media regarding terrorism issues have been greatly influenced by the responses of the sample members, with weighted average of (3.88) and a standard deviation of (1.49).

To answer the second question of the study, the effects of dependence table (2) illustrates the cognitive, emotional and behavioral effects of Saudi university students' reliance on the media regarding terrorism issues.

\begin{tabular}{|l|l|}
\hline Effects & relative weight \\
\hline Emotional & $85.0 \%$ \\
\hline Cognitive & $79.4 \%$ \\
\hline Behavioral & $68.5 \%$. \\
\hline Total & $78.9 \%$. \\
\hline
\end{tabular}

Table 2 shows that the relative weight of the total effects was $78.9 \%$. The highest emotional effects were $85.0 \%$, followed by cognitive effects with a relative weight of $79.4 \%$ and behavioral effects with a relative weight of $68.5 \%$. The high percentage of emotional effects may be due to the fact that the cognitive and behavioral effect is replaced by emotional and affection impact, as well as the feeling of helplessness of the behavioral effect that may turn into suppression or affective effect.

\section{Recommendations}

Based on the data and results of the theoretical and field study, the researcher presents the following recommendations and proposals:

1 - The adoption of objective media means in addressing various issues and problems, and raise the level of credibility in the dissemination of news and follow-up events.

2- Training Arab media professionals and preparing them to deal with the phenomenon of terrorism and extremism in a professional way.

3- Directing all awareness, political culture, and various media tools to be effective in the development of youths' perceptions and potentials to address the phenomenon of terrorism and extremism that afflicts societies.

4- Enhancing media exchange between satellite channels to combat and eliminate the phenomenon of terrorism and extremism through the preparation of programs and studies on this phenomenon.

5 - Intensification of intellectual correction programs using various means of mass communication, especially social networks.

\section{References}

Abadie and Gardeazabal (2015) Terrorism and the World Economy

Adam Bazcko and others, The Rationality of an Eschatological Movement: The Islamist State in Iraq and Syria, Working Paper (United State: Yale University, The MacMillan Center, The Program on Governance and Local Development, No. 7, 2016), p. 26.

Aldo Borgu, Costs and Benefits of the US Alliance in an Age of Terrorism, A presentation to the Asia-Pacific College of Diplomacy Conference on The Australian American Alliance Canberra 1-2 December 2016.

Christopher M. Blanchard and Carla E. Humud, The Islamic State and U.S. Policy, Report for Congress (Washington: Congressional Research Service, No. R43612, 2017), p. 10.

Cole Bunzel, From Paper State to Caliphate: The Ideology of the Islamic State, Analysis Paper (Washington: Center for Middle East Policy, No. 19, March 2015), p.p. $31-32$.

Current History, ISIS and the Third Wave of Jihadism (United States: Philadelphia, Daniel Mark Redmond, Vol. 113, No. 767, December 2014 ), p. 341.

Fawaz A. Gerges, ISIS and the Third Wave of Jihadism, Current History (United States: Philadelphia, Daniel Mark Redmond, Vol. 113, Issue. 767, December 2014), p. 342.

Government of the United Kingdom, National Security Strategy and Strategic Defence and Security Review 2015: First Annual Report 2016 (London: Government of the United Kingdom, 2016), p. 5.

Yoo, John, Terrorism, the Laws of War, and the Constitution (2016) USA: Hoover Institution Press. 